\title{
PERAN PENGALAMAN SEBAGAI PEMODERASI PADA PENGARUH PENGETAHUAN DAN SIKAP WISATAWAN MANCANEGARA TERHADAP KEPUTUSAN PEMBELIAN PRODUK WELLNESS TOURISM DI KAWASAN WISATA UBUD, KABUPATEN GIANYAR
}

\author{
Dewa Putu Kiskenda Erwanda Putra \\ I Wayan Suardana \\ Luh Gede Leli Kusuma Dewi \\ Email : kiskenda@gmail.com \\ PS. S1 Industri Perjalanan Wisata \\ Fakultas Pariwisata UNUD
}

\begin{abstract}
ABSTRAK
Pariwisata wellness utamanya Spa di kawasan wisata Ubud tumbuh pesat mencapai 54,17\% (dalam 3 tahun terakhir) dengan jumlah sebanyak 96 Spa dengan kategori Day Spa dan Hotel and Resort Spa. Industri Spa di Ubud sebagai industri pariwisata yang akan diunggulkan kedepannya penting dalam selalu memenuhi permintaan wisatawan dengan output terciptanya keputusan pembelian secara berkelanjutan. Pengambilan keputusan sangat erat kaitanya dengan keterlibatan psikologis, favoritism dan sense of goodwill yang awalnya muncul dari internal diri wisatawan, oleh karenanya penting dilakukan penelitian dengan pendekatan pada pengetahuan, sikap dan sekaligus mengukur peran pengalaman dalam memperkuat pengaruh pengetahuan dan sikap terhadap keputusan pembelian produk wisata Spa di Ubud. Sampel dalam penelitian ini ditentukan secara purposive yaitu wisatawan mancanegara yang membeli produk layanan Spa di kawasan wisata Ubud sebanyak 250 wisatawan. Sedangkan analisis data yang dilakukan meliputi analisis deskriptif, analisis pengujian instrumen data dan Moderated Regression Analysis (MRA) dengan menggunakan pendekatan interaksi. Hasil penelitian menunjukan bahwa (1) pengalaman secara signifikan berperan sebagai pemoderasi yang memperkuat pengaruh antara pengetahuan terhadap keputusan pembelian dan (2) pengalaman juga secara signifikan sebagai pemoderasi yang memperkuat pengaruh sikap terhadap keputusan pembelian produk wisata Spa di kawasan wisata Ubud.
\end{abstract}

Kata Kunci : Keputusan Pembelian, Pengalaman, Pengetahuan, Sikap.

\section{PENDAHULUAN}

Bali sebagai destinasi wisata health and wellness, telah populer sebagai salah satu destinasi Spa terbaik dan telah meraih predikat The Best destination Spa in Asia pada Asia Spa and Wellness Festifal Gold Award di Bangkok, dan The Best Spa di Dunia oleh Berlin Based Fitness Magazine Senses pada Annual ITB, Berlin tahun 2009. Bali memiliki potensi yang sangat besar atas kedua aset (Existing assets \& Use of existing assets), serta pada sisi yang sama adanya dukungan dari lingkungan bisnis yang teratur baik telah berdampak positif terhadap berkembang dengan pesatnya wisata wellness dalam 10 tahun terakhir (widjaya, 2011).

Wijdaya (2011) mengemukakan, salah satu produk utama wellness yaitu Spa di Bali tumbuh dengan jumlah melebihi $160 \%$ dalam waktu 8 tahun. Terhitung sejak tahun 2003 sampai dengan tahun 2011 teridentifikasi ada sekitar 410 Spa yang beroperasi dan tersebar pada pusat-pusat aktivitas wisata. Diantara beberapa kawasan wisata tersebut, Ubud berperan dan berkontribusi secara aktif sebagai host dalam menyediakan sarana Spa dengan jumlah sekitar 97 usaha sejenis.

Karakteristik produk wisata wellness yang berkembang di Ubud masih didominasi aktivitas 
Spa. Pertumbuhan jasa sarana Spa meningkat cukup signifikan diantaranya usaha Resort Spa dan Day Spa yang tersebar pada kawasan wisata Ubud terutama di Keluharan Ubud, Desa Campuan dan Desa Kedewatan.

Pada studi pendahuluan teridentifikasi 96 usaha Spa dengan kategori Day Spa dan hotel/resort Spa yang tersebar di areal kelurahan Ubud, Desa Campuhan dan Desa Kedewatan. Pertumbuhan usaha Spa meningkat sebesar $54,17 \%$ sebagai bukti atas meningkatnya permintaan wisatawan untuk aktivitas wisata wellness tersebut (Data hasil peneltian, 2015).

Industri Spa sebagai produk pariwisata yang akan diunggulkan kedepannya sangat penting untuk dikelola secara baik dalam menjaga citra Ubud sebagai destinasi wisata wellness dimata wisatawan, oleh karenannya perlu upaya-upaya untuk menjaga agar wisatawan yang menggunakan jasa Spa terpenuhi kebutuhan dan keinginannya yang berakhir pada terciptannya keputusan pembelian wisatawan secara berkelanjutan. Perlu dilakukan penelitian terhadap faktor-faktor yang cenderung mempengaruhi wisatawan terhadap pengambilan keputusan pembelian produk wisata Spa sebagai output atas pelayanan wisata wellness di kawasan wisata Ubud terlebih lagi pengaruh faktor internal yang berasal dari wisatawan atau customer itu sendiri di dalam menciptakan keputusan pembelian wisatawan terhadap produk wisata wellness.

Jacoby dan Ohestnut, 1978 (dalam Rudyanto, 2012) menyebutkan bahwa keputusan pembelian dapat diukur salah satunya dengan pendekatan sikap. Pendekatan sikap dapat mengungkapkan keputusan pelanggan dari aspek keterlibatan psikologis, favoritisme, dan sense of goodwill pada produk jasa (Oh, 1995 dalam Rudyanto, 2012).

Menurut Prabawa dan Trapika (2014) ada korelasi atau hubungan antara sikap dan pengetahuan terhadap pemanfaatan sarana wisata, dan dapat diinterprestasikan bahwa pengetahuan dan sikap juga bisa berpengaruh terhadap keputusan wisatawan dalam melakukan pembelian. Dalam hal ini juga perlu mempertimbangkan peran pengalaman dalam memperkuat hubungan terhadap keputusan pembelian. Penelitian Sukmadinata (2007) dan penelitian Mowen dan Minor (2002) masing-masing menjelaskan bahwa pengalaman sebagai faktor yang mempengaruhi dan cenderung meningkatkan pengaruh pengetahuan dan sikap terhadap keputusan pembelian yang berfungsi sebagai variabel moderasi.

Pengalaman sebagai variabel pemoderasi juga telah dibuktikan oleh penelitian yang dilakukan oleh Bennet, et, al (2005) dan Patterson, et, al, (1995). Maka dari itu, untuk menguji kebenarannya perlu dilakukan analisis peran pengalaman sebagai pemoderasi terhadap pengaruh pengetahuan (knowledge) wisatawan dan sikap wisatawan terhadap keputusan wisatawan dalam pembelian produk wisata Spa, sehingga nantinya hasil analisis dapat dipakai sebagai pertimbangan bagi para pengusaha Spa di kawasan wisata Ubud dalam membuat dan memasarkan produk yang berakhir pada keputusan pembelian atas produk-produk Spa tersebut.

\section{METODE}

Dalam penelitian ini terdiri atas variabel bebas, yaitu pengetahuan wisatawan $\left(\mathrm{X}_{1}\right)$ dan Sikap wisatawan $\left(\mathrm{X}_{2}\right)$, variabel terikat yaitu keputusan pembelian (Y) dan pengalaman konsumsi sebagai variabel moderasi $(Z)$ yang dapat dijelaskan pada kerangka pemikiran berikut

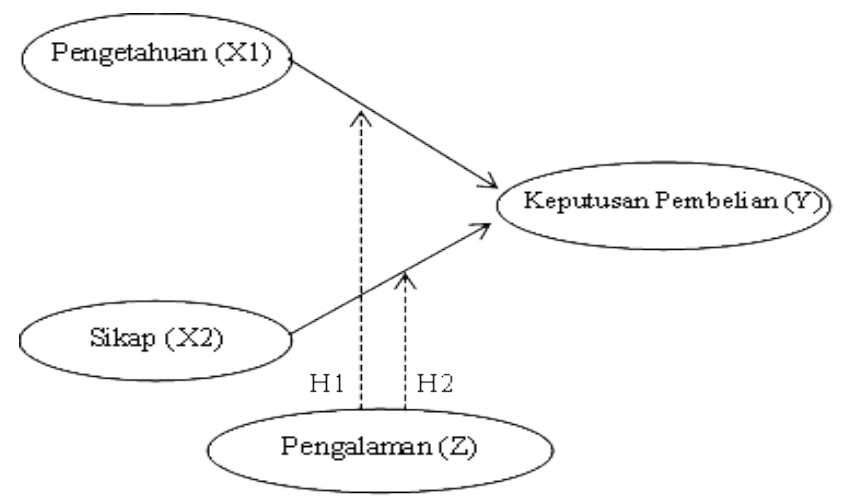

Gambar 1. Kerangka Pemikiran

ini.

Jenis data yang dikumpulkan dalam penelitian ini terdiri dari data kualitatif dan data kuantitatif. Penelitian ini menggunakan data primer diantaranya data hasil penyebaran kuesioner pada sampel responden dan data Teknik penentuan sampel dalam penelitian ini secara purposive sampling yaitu wisatawan mancanegara yang membeli produk layanan Spa di kawasan wisata Ubud. Jumlah sampel mengacu pada model penentuan jumlah sampel yang dikemukakan oleh J. Supranto (dalam Widyasrama, 2014). Dalam penelitian ini jumlah indikator yang dipergunakan sebanyak 25, maka jumlah responden yang akan dijadikan sampel 
adalah 250 orang yang diperoleh dengan mengalikan jumlah indikator penelitian (25)

\begin{tabular}{lccc}
\hline No. Variabel & $\begin{array}{c}\text { Cronbach's } \\
\text { Alpha }\end{array}$ & $\begin{array}{c}\text { Standard } \\
\text { Alpha } \\
\text { Cronbach }\end{array}$ & Ket. \\
\hline 1. Pengetahuan $\left(\mathrm{X}_{1}\right)$ & 0,751 & 0.60 & Reliabel \\
\hline 2. Sikap $\left(\mathrm{X}_{2}\right)$ & 0,686 & 0.60 & Reliabel \\
\hline $\begin{array}{l}\text { Keputusan } \\
\text { Pembelian }(\mathrm{Y})\end{array}$ & 0,748 & 0.60 & Reliabel \\
\hline 4. Pengalaman $(\mathrm{Z})$ & 0,616 & 0.60 & Reliabel \\
\hline
\end{tabular}

dengan 10.

Teknik analisis data yang digunakan dalam penelitian ini adalah teknik analisis kuantitatif, yaitu Moderated Regression Analysis (MRA) untuk menguji bentuk moderasi dengan menggunakan pendekatan interaksi (Sugiono, 2004) yang dapat dihitung dengan menggunakan alat bantu komputer yaitu program SPSS (Statistical Package for the Social Science) 14.00 for windows. Dengan menggunakan pendekatan Moderated Regression maka variabel dapat dikelompokan berdasarkan hubungan dimensi (dalam Sugiono, 2004) yaitu (1) Pure moderation (moderasi murni), apabila hasil pengujian secara parsial tidak signifikan dan pengujian secara interaksi menunjukan hasil yang signifikan, (2) Quasi moderation (moderasi semu) artinya variabel dapat sebagai variabel moderator dan variabel independen, apabila hasil pengujian secara parsial maupun interaksi menunjukan hasil yang sama-sama signifikan dan (3) Homologizer moderation (moderasi berpotensi), apabila hasil pengujian secara parsial maupun interaksi menunjukan hasil yang sama-sama tidak signifikan.

\section{PEMBAHASAN}

1. Hasil Uji Kualitas Data

a) Uji Validitas

Tabel.1. Nilai Validitas dalam Analisis

\begin{tabular}{|c|c|c|c|c|c|c|}
\hline No & $\begin{array}{c}\text { Faktor } \\
\text { Variabel }\end{array}$ & Indikator KMO & $\begin{array}{c}\text { Total } \\
\text { Varians } \\
\text { Kumulati }\end{array}$ & $\begin{array}{l}\text { Load } \\
\text { Faktor }\end{array}$ & Sig. & Ket. \\
\hline 1. & Pengetahuan $\left(\mathrm{X}_{1}\right)$ & $X_{1.1}-X_{1.7}, 764$ & 59,291 & $>, 50$ & 000 & Valid \\
\hline & Sikap $\left(\mathrm{X}_{2}\right)$ & $\mathrm{X}_{2.1}-\mathrm{X}_{2.8}, 663$ & 63,917 & $>, 50$ & 000 & Valid \\
\hline 3. & $\begin{array}{l}\text { Keputusan } \\
\text { Pembelian (Y) }\end{array}$ & $\mathrm{Y}_{1}-\mathrm{Y}_{7}$ & 58,373 & $>, 50$ & 000 & Valid \\
\hline 4. & Pengalaman (Z) & $\mathrm{Z}_{1}-\mathrm{Z}_{3}$ & 59,941 & $>, 50$ &, 000 & Valid \\
\hline
\end{tabular}

Sumber; hasil olahan komputer
Hasil uji validitas pada Tabel.1 di atas, dapat diketahui bahwa, semua variabel memilki nilai Kaiser-Meyer-Olkin (KMO) Measure of Sampling Adequacy (MSA) $\geq 0.05$, signifikan pada $\leq 0,05$, total varians komulatif $\geq 50 \%$ dan nilai factor loading $\geq 0,50$ sehingga dapat disimpulkan bahwa seluruh data dari variabel-variabel penelitian ini adalah valid atau sahih

b) Uji Reliabilitas

\section{Tabel.2 Hasil Uji Reliabilitas}

Hasil uji reliabilitas pada Tabel.2 di atas menunjukan bahwa koefisien Alpha Cronbach dari masing-masing variabel lebih dari standard Alpha Cronbach 0,60, sehingga data dari semua variabel penelitian ini dapat dinyatakan reliabel.

\section{Hasil MRA (Moderated Regression Analysis)}

Hasil pengujian Moderated Regression Analysis (MRA) yang memperkuat pengaruh pengetahuan dan sikap wisatawan terhadap keputusan pembelian produk wisata Spa dapat disusun dalam dua model persamaan sebagai berikut.

a) Model persamaan regresi moderasi 1 , untuk pengaruh pengalaman dalam memperkuat hubungan pengetahuan terhadap keputusan pembelian.

$\mathrm{Y}=-9,044+0,856 \mathrm{X}_{1}+2,999 \mathrm{Z}+0,068 \operatorname{Mod} 1+\mathrm{e}$

Tabel.3. Hasil Regresi Moderasi 1

\begin{tabular}{|c|c|c|c|c|c|c|}
\hline \multirow{2}{*}{ Variabel } & \multirow{2}{*}{$\begin{array}{l}\text { Keputusan } \\
\text { Pembelian }\end{array}$} & \multicolumn{2}{|c|}{ Uji F } & \multicolumn{2}{|c|}{ Uji t } & \multirow{2}{*}{$\underset{2}{\operatorname{Adj} R}$} \\
\hline & & $\mathbf{F}$ & Sig & $\mathbf{t}$ & Sig & \\
\hline Pengetahuan $\left(\mathrm{X}_{1}\right)$ & 0,856 & & & 3,095 &, 002 & \\
\hline Pengalaman (Z) & 2,999 & 59,177 &, 000 & 5,030 &, 000 & ,412 \\
\hline Moderat 1 & 0,068 & & & 3,009 &, 003 & \\
\hline
\end{tabular}

Sumber; hasil olahan komputer

Persamaan tersebut menjelaskan variabel pengetahuan memberikan nilai koefisien parameter sebesar 0,856 dengan tingkat signifikansi 0,002 . Variabel pengalaman memberikan nilai koefisien parameter sebesar 2,999 dengan tingkat signifikansi 0,000 , dan variabel moderat 1 memberikan nilai koefisien parameter sebesar 0,068 dengan tingkat signifikansi sebesar 0,003 . Dengan demikian variabel moderat 1 yang merupakan interaksi antara pengetahuan dan pengalaman ternyata 
signifikan, sehingga dapat disimpulkan bahwa variabel pengalaman merupakan variabel moderating yang bersifat Quasi moderation (moderasi Semu)

Nilai F hitung diperoleh sebesar 59,177 dengan tingkat signifikansi sebesar 0,000 . Dengan probabilitas signifikansi jauh lebih kecil dari 0,05 , maka model regresi ini dapat digunakan untuk memprediksi keputusan pembelian produk wisata Spa dan dapat dikatakan bahwa pengetahuan, pengalaman dan moderat 1 (interaksi pengetahuan dan pengalaman) secara bersama-sama berpengaruh terhadap keputusan pembelian produk Spa di Kawasan Wisata Ubud.

Tabel.3 menunujukan nilai adjusted $\mathrm{R}^{2}$ sebesar 0,412 atau $41,2 \%$ yang berarti bahwa $41,2 \%$ variasi keputusan pembelian dapat dijelaskan oleh variabel pengetahuan, pengalaman dan moderat 1 . Sedangkan sisanya $(100 \%-41,2 \%=58,8 \%)$ dipengaruhi atau dijelaskan oleh variabel lainnya. Sehingga dapat disimpulkan bahwa hipotesis pertama yaitu ada pengaruh positif dan signifikan pengetahuan wisatawan terhadap keputusan pembelian produk Spa di kawasan wisata Ubud yang dimoderasi oleh pengalaman wisatawan dapat diterima.

b) Model persamaan regresi moderasi 2, untuk pengaruh pengalaman dalam memperkuat hubungan sikap terhadap keputusan pembelian.

$$
Y=-50,985+2,254 X_{2}+5,567 Z+0,154 \operatorname{Mod} 2+e
$$

Tabel.4. Hasil Regresi Moderasi 2

\begin{tabular}{|c|c|c|c|c|c|c|}
\hline \multirow{2}{*}{ Variabel } & \multirow{2}{*}{$\begin{array}{l}\text { Keputusan } \\
\text { Pembelian }\end{array}$} & \multicolumn{2}{|c|}{ Uji F } & \multicolumn{2}{|c|}{ Uji t } & \multirow{2}{*}{$\begin{array}{l}\text { Adj } \\
\mathbf{R}^{2}\end{array}$} \\
\hline & & $\mathbf{F}$ & Sig & $\mathbf{t}$ & Sig & \\
\hline Sikap $\left(\mathrm{X}_{2}\right)$ & 2,254 & \multirow{3}{*}{93,006} & \multirow{3}{*}{5,000} & 7,422 & ,000 & \multirow{3}{*}{0,526} \\
\hline Pengalaman (Z) & 5,567 & & & 8,006 & ,000 & \\
\hline Moderat 2 & 0,154 & & & 6,631 & ,000 & \\
\hline
\end{tabular}

Sumber: Hasil olahan Komputer

Persamaan di atas menunjukan bahwa variabel sikap memberikan nilai koefisien parameter sebesar 2,254, selanjutnya variabel pengalaman dengan nilai koefisien parameter sebesar 5,567 dan variabel moderat 2 dengan nilai koefisien parameter sebesar 0,154 dengan tingkat signifikansi untuk ketiga variabel sebesar $0,000 \quad(<0,05)$. Dengan demikian variabel moderat 2 yang merupakan interaksi antara variabel sikap dan variabel pengalamanan ternyata dinyatakan signifikan, sehingga dapat disimpulkan bahwa variabel pengalaman merupakan variabel moderating yang bersifat Quasi moderation (moderasi Semu). Hal ini berdasarkan atas pengujian hipotesis secara parsial dan hasil uji interaksi yang menunjukan hasil yang sama-sama signifikan terhadap keputusan pembelian.

Hasil uji $\mathrm{F}$ pada Tabel.4 menghasilkan nilai $\mathrm{F}$ hitung sebesar 93,006 dengan tingkat signifikansi sebesar 0,000 . Dengan probabilitas signifikansi jauh lebih kecil dari 0,05, maka model regresi ini dapat digunakan untuk memprediksi keputusan pembelian produk wisata Spa dan dapat dikatakan bahwa variabel sikap, variabel pengalaman dan moderat 2 (interaksi sikap dan pengalaman) secara bersama-sama berpengaruh terhadap keputusan pembelian produk Spa di kawasan wisata Ubud.

Nilai adjusted $\mathrm{R}^{2}$ diperoleh sebesar 0,526 $(52,6 \%)$ yang berarti bahwa $52,6 \%$ variasi keputusan pembelian dapat dijelaskan oleh variabel sikap, variabel pengalaman dan variabel moderat 2 , sedangkan sisanya $(100 \%-52,6 \%=$ $47,4 \%$ ) dipengaruhi atau dijelaskan oleh sebab-sebab lain di luar model. Sehingga dapat disimpulkan bahwa hipotesis kedua yaitu ada pengaruh positif dan signifikan sikap wisatawan terhadap keputusan pembelian produk Spa di kawasan wisata Ubud yang dimoderasi oleh pengalaman wisatawan dapat diterima.

Pengalaman wisatawan pada penelitian ini sebagai variabel moderator dari pengaruh pengetahuan wisatawan pada keputusan pembelian produk Spa. Hasil pengujian hipotesis mendukung bahwa pengalaman sebagai variabel pemoderasi dengan diperolehnya tingkat signifikasi sebesar 0,000 yang menjelaskan bahwa semakin tinggi pengalaman pembelian produk Spa akan meningkatkan pengaruh pengetahuan wisatawan terhadap keputusan pembelian produk Spa.

Hasil penelitian ini sesuai dengan penelitian menurut Sukmadinata (2007), bahwa pengalaman merupakan salah satu faktor yang mempengaruhi pengetahuan konsumen. Hal ini dikarenakan ketika wisatawan telah memiliki pengalaman konsumsi atas suatu produk, maka akan mempengaruhi tingkat pengetahuan wisatawan atas produk tersebut. Semakin banyak 
pengalaman seseorang terhadap produk, maka pengetahuan orang tersebut akan lebih banyak tentang produk, sehingga akan lebih baik dalam mengambil keputusan pembelian produk wisata Spa di kawasan wisata Ubud.

1. Pengalaman sebagai pemoderasi pada pengaruh sikap wisatawan mancanegara terhadap keputusan pembelian produk wisata Spa

Hasil pengujian hipotesis kedua menunjukan bahwa pengalaman merupakan variabel pemoderasi yang meningkatkan pengaruh sikap wisatawan pada keputusan pembelian produk wisata Spa di kawasan wisata Ubud. Hipotesis ini konsisten dengan hasil penelitian sebelumnya yang dilakukan oleh Mowen dan Minor (2002) yang menyatakan pengalaman berpengaruh terhadap pembentukan sikap konsumen. Pengalaman yang positif dan cenderung puas akan berdampak pada sikap yang positif dan mengarah pada pembelian ulang dan begitu juga ketika pengalaman konsumen bersifat negatif setelah mengkonsumsi produk, maka akan berdampak negatif pada sikap. Apakah nantinya mengkonsumsi lagi atau mengurangi mengkonsumsi atau bahkan tidak memakai produk itu lagi, semua akan terekam dalam ingatan konsumen (Dwiastuti, dkk; 2012).

Sehingga dalam penelitian ini, terbukti bahwa pengalaman telah memperkuat sikap wisatawan terhadap keputusan pembelian produk wisata Spa di kawasan wisata Ubud.

\section{SIMPULAN DAN SARAN}

\section{Simpulan}

(1) Pengalaman secara signifikan berperan sebagai pemoderasi yang memperkuat pengaruh antara pengetahuan terhadap keputusan pembelian.

(2) Pengalaman pembelian produk Spa secara signifikan berperan sebagai pemoderasi yang memperkuat pengaruh antara sikap wisatawan terhadap keputusan pembelian wisatawan pada produk Spa di kawasan wisata Ubud.

\section{Saran}

(1) Hasil pada penelitian ini menyimpulkan bahwa pengalaman wisatawan sebagai variabel pemoderasi memiliki sifat Quasi Moderasi atau moderasi semu yang artinya pengalaman dapat sebagai variabel moderator dan juga berfungsi sebagai variabel prediktor atau independen. Dengan demikian pada penelitian selanjutnya diharapkan dapat menganalisis peran pengalaman konsumen sebagai variabel bebas dalam mempengaruhi pengambilan keputusan seorang konsumen.

\section{DAFTAR PUSTAKA}

Bennett, R., Hartel, C.E.J., McColl-Kennedy, J.R. .2005, Experience as a moderator of involvement and satisfaction on brand loyalty in a business-to-business setting, Journal Industrial Marketing Management, Vol. 34 No. 1, pp. 97-107.

Dwiastuti, R, Shinta, A, dan Isaskar, R. 2012. Ilmu Prilaku Konsumen. Malang : Universitas Brawijaya Press.

Mowen, J dan Minor, M. 2002. Prilaku Konsumen Jilid 1 Edisi Kelima. Jakarta : Erlangga.

Patterson, P.G., Johnson, L. 1995, Focal brand experience and product based norms as moderators in the satisfaction formation process, Journal of Consumer Satisfaction, Dissatisfaction and Complaining Behaviour, Vol. 8, pp. 22-31

Prabawa, I P dan Trapika, I G M. 2014. Hubungan antara Sikap \& Tingkat Pengetahuan Seputar Klinik Wisata pada Wisatawan Domestik maupun Mancanegara terhadap Pemanfaatan Klinik Wisata di Kawasan Wisata Pantai Kuta, Bali. Jurnal ilmiah mahasiswa kedokteran Indonesia.Vol. 2, no. 2, Januari - Juni 2014

Rudyanto.2012. Pengaruh Nilai Persepsi Terhadap Loyalitas Pelanggan Dengan Ekuitas Destinasi Sebagai Moderasi Pada Wisata Kesehatan Spa Dki Jakarta. Jurnal Hospitour Vol. III, no. 2. hal.

Sugiono. 2004. Konsep, Identifikasi, Alat Analisis dan Masalah Penggunaan Variabel Moderator. Jurnal Studi Manajemen \& Organisasi, Vol.1, No.2 hal. 61-70.

Sukmadinata, N S. 2007. Landasan Psikologi Proses Pendidikan. Bandung : Remaja Rosdakarya.

Widjaya, Lulu. 2011. Spa Industry in Bali. Guest Lecturer Program Doktor kajian Pariwisata di Universitas Udayana

Widyasrama, I B M. 2014. Pengaruh Brand Image dan Perceived Quality terhadap Pengambilan Keputusan Wisatawan dalam Pembelian Produk Watersport di Tanjung Benoa. Laporan Skripsi. Fakultas Pariwisata 
Jurnal IPTA

ISSN : 2338-8633

Vol. 3 No. 1, 2015

Universitas Udayana. 